\title{
The Influence of Microalloying on the Thermal Treatment of Aluminum Bronzes
}

Iva Nová, Jiří Machuta, Luboš Raur

Faculty of Mechanical Engineering, Technical University of Liberec, Studentská 2, 46117 Liberec 1, Czech Republic. E-mail: iva.nova@tul.cz, jiri.machuta@tul.cz,raur.1@slevarna.cz

At present, with the development of electric vehicles, great attention is paid to alloys which have very good electrical conductivity, corrosion resistance and resist to high temperatures. These alloys include aluminum bronzes. The electrical conductivity is the higher the finer is the grain or the less it contains almost non-conductive oxides, non-metallic inclusions, porosity, etc. Aluminum bronzes are foundry alloys that exhibit good electrical properties, very good sliding properties at high mechanical values, are resistant to corrosion and heat, have high resistance to acids and alkalis, so they are successfully used to work in aggressive environments. Aluminum increases strength and hardness, approximately $10 \mathrm{wt}$. \% Al dissolves in copper, the alloy structure consists only of crystals $\alpha$ (cubic surface centered grid). Higher Al content also produces fragile crystals $\gamma_{2}$ (Cu9A14) and the alloy is harder and more fragile. The properties of aluminum bronzes with the structure of crystals $\left(\alpha+\gamma_{2}\right)$ have a considerable influence on the cooling rate. Foundry bronzes are also used for more loaded wreath of gears, screw wheels, pump seats, impellers and distributor wheels, heavy load bushings and plain bearings.

Keywords: Aluminium bronzes, microlloying, microstructure.

\section{Acknowledgement}

This publication was written at the Technical University of Liberec as part of the Student Grant Contest "SGS 21122 " with the support of the Specific University Research Grant, as provided by the Ministry of Education, Youth and Sports of the Czech Republic in the year 2017.

\section{References}

[1] PÍŠEK, F. et al. (1973). Nauka o materiálu I - Nauka o kovech. Neželezné kovy. (Material science - Science of metals, Nonferrous metals). Praha (in Czech).

[2] GRÍGEROVÁ, T. et al. (1988). Zlievárenstvo neželezných kovov. (Non-ferrous metal foundry). Bratislava/Praha (in Slovak).

[3] ROUČKA, J. (2004). Metalurgie neželezných slitin. (Metallurgy of non-ferrous alloys). Brno (in Czech).

[4] PISAREK, B.P. (2013). Model of Cu-Al-Fe-Ni Bronze Crystallization. Archiver of Foundry engineering. Vol 13 Iss. 3/2013 p. 72-79, ISSN (1897-3310).

[5] BREZINA, P. (1973). Gefügeumwandlungen und mechanische Eigenschaften der Mehrstoff-Aluminiumbronzen vom Typ CuAl10 Fe5 Ni5. Giesserei-Forschung. 25(3), 1-10.

[6] BREZINA, P. (1973). Gefögeumwandlungen und mechanische Eigenschaften der Mehrstoff-Aluminiumbronzen vom Typ CuAl 10 Fe5 Ni5. Giesserei-Forschung, 25(3), 1-10 (in Germany).

[7] COOK, M., FENTIMEN, W.P. \& DAVIS, E. (1951-52). Observations on the structure and properties of wrought cooper-aluminiumnickel-iron alloys, J. Inst. Metals. 80, 419/29.

[8] JAHANAFROOZ, A., HASAN, F., LORIMER, G.W. \& RIDLEY, N. (1983). Microstructural Development in Complex Nickel-Aluminum Bronze. Met. Trans A. 14a, 1951-1956.

[9] FULLER, M.D. (2006). Friction Stir Processing and Fusion Welding in Nickel Aluminum Propeller Bronze. Thesis, Thesis Advisor: Terry R. McNelley, Naval Postgraduate School, Monterey, California, USA

[10] HASAN, F., JAHANAFROOZ, A., LORIMER, G.W. \& RIDLEY, N. (1982). The Morphology, Crystallography, and Chemistry of Phases in As-Cast Nickel-Aluminum Bronze. Met. Trans A. 13a, 1337- 1345.

[11] PISAREK, B. (2007). The crystallization of the bronze with additions of Si, Cr, Mo and/or W. Archives of Materials Science and Engineering. 28(8), 461-466.

[12] PISAREK, B. (2010). Influence of the technology of melting and inoculation preliminary alloy AlBe5 on change of concentration of $\mathrm{Al}$ and microstructure of the bronze CuAl10Ni5Fe4. Archives of Foundry Engineering. 10(2), 127-134.

[13] PISAREK, B. (2011). Effect of additions Cr, Mo, W and/or Si on the technological properties on the technological properties of aluminium-iron-nickel bronze. Archives of Foundry Engineering. 11(3), 199-208. 
[14] PISAREK, B. (2012). Effect of annealing time for quenching CuAl7Fe5Ni5W2Si2 bronze on the microstructure and mechanical properties. Archives of Foundry Engineering. 12(2), 187- 204.

[15] PIETROWSKI, S. PISAREK, B. (2007). Computer-aided technology of melting high-quality metal alloys. Archives of Metallurgy and Materials. 52(3), 481-486.

[16] RAUR, Luboš. (2016). Metalurgie a mechanické hodnoty odlitků ze slitin mědi. (Metallurgy and mechanical properties of copper alloy castings). Diplomová práce. (Thesis). KSP, FS - TU v Liberci 2016. (in Czech).

[17] HÁJEK, J., KŘÍŽ, A., HRDLIČKA, V. (2015). Tepelné zpracování hliníkových bronzů, (Heat treatment of the aluminium bronzes). Západočeská univerzita v Plzni, článek projektu, SGS - 2012-044, Plzeň, s. 2 - 5 (in Czech).

[18] European Copper Institute Cupper Alliace: $\mathrm{Cu}$ - Al phase quillibrium system.

[19] MIROSLAV, G., MILENA, W. (2013). Elimination of the negative effect of fe-rich intermetallic phases in secondary (recycled).aluminium cast alloy. In: Manufacturing Technology. Vol. 11, No. 1, pp. 17 - 22. ISSN 1213 2489.

[20] HURTALOVÁ, L., TILlOVÁ, E. (2013). Elimination of the negative effect of fe-rich intermetallic phases in secondary (recycled).aluminium cast alloy. In: Manufacturing Technology. Vol. 13, No. 1, pp. 44 - 50. ISSN 1213 2489 .

[21] HÁJEK, J., KŘÍŽ, A., HRDLIČKA, V. (2015). The Heat Treatment of Aluminium Bronzes. In: Manufacturing Technology. Vol. 15, No. 1, pp. 35 - 41. ISSN 1213-2489. 